\title{
A PROBABLE EXAMPLE OF R-FACTOR RECOMBINATION IN THE HUMAN GASTRO-INTESTINAL TRACT
}

\author{
L. C. Ingram, J. D. Anderson*, Janet E. Arrand and M. H. Richmond \\ Department of Bacteriology, University of Bristol Medical School, Bristol BS8 ITD
}

TRANSFERABLE drug-resistance factors ( $R$ factors) conferring resistance to more than one antibiotic may be formed by mutation of an existing $R$ factor, by " pick-up " of chromosomal genes, or by recombination between different $\mathrm{R}$ factors. The last mechanism was favoured by Clowes (1972) in his recent review of the molecular structure of bacterial plasmids. Recombination between $\mathrm{R}$ factors has been demonstrated in the laboratory (Yokota et al., 1969; Nisioka, Mitani and Clowes, 1970), but has not been reported to have occurred in man. The appearance of a second R factor in Shigella sonnei without recombination has been observed during treatment of a case of human dysentery with kanamycin (Farrar et al., 1972).

Previous studies described the isolation of Escherichia coli strains from the faeces of persons who had been fed with a strain of $E$. coli carrying the $\mathrm{R}$ factor R1 (Anderson, Gillespie and Richmond, 1973a; Anderson et al., 1973b). The investigations showed the presence of an R factor R174 (ACKSSuT) conferring resistance to ampicillin (A), chloramphenicol (C), kanamycin (K), streptomycin (S), sulphonamide (Su) and tetracycline $(\mathrm{T})$. This $\mathrm{R}$ factor was originally identified in a strain of $E$. coli serotype 09 isolated from a person who had ingested a strain of $E$. coli serotype $\mathrm{O} 2$ carrying R1 (resistant to ACKSSu). A second $E$. coli isolate of serotype $\mathrm{O} 9$ was found to carry resistance to ampicillin, streptomycin and tetracycline R157 (AST). This paper presents evidence that R174 is a recombinant between R1 and R157 including the streptomycinresistance determinants of both, as well as the other resistance markers.

\section{MATERIALS AND METHODS}

Bacterial strains and $R$ factors. The four $\mathrm{R}$ factors used in this study are $\mathrm{R} 1, \mathbf{R} 222$, R157 and R175. The first two of these were described respectively by Meynell and Datta (1966) and Watanabe and Fukasawa (1961). The latter two were carried by E. coli serotypeO9 strains isolated from the gastro-intestinal tract of a single person who had ingested an $E$. coli strain carrying R1 (Anderson et al., 1973a). These three R factors were transferred into $E$. coli strain NxR and into $E$. coli strain NC22, a strain free from covalently closed, circular (CCC), plasmid DNA (Grinsted et al., 1972).

E. coli strain UB276 nal $^{\mathrm{r}}$ was a spontaneous nalidixic acid-resistant derivative of strain JC5774 (recA). The strain of Proteus mirabilis was obtained from Dr J. Bishop, University of Edinburgh. The I-like $\mathrm{R}$ factor used for compatibility studies was from $E$. coli strain $18 \mathrm{M}-1$ tet $^{\mathrm{s}}$, a spontaneous tetracycline-sensitive mutant of strain $18 \mathrm{M}$ isolated from sewage. It was resistant to neomycin, kanamycin, tetracycline, streptomycin and ampicillin.

Received 4 July 1973; accepted 28 Sept. 1973.

* Present address: Group Pathology Laboratories, County Hospital, York, YO3 7PG.

J. MED. MICROBIOL.-VOL. 7 (1974) 
The media used in these experiments have been described by Anderson et al. (1973a) and Ingram et al. (1972).

$\beta$-Lactamase assays and titration with antiserum. Estimations of $\beta$-lactamase activity were made on lysates of cultures, after ultrasonic disintegration, by iodometric titration (Perret, 1954) with ampicillin as substrate (Novick, 1962). Titration with antiserum was performed as described by Datta and Richmond (1966); enzyme prepared from a strain of $E$. coli carrying the $\mathrm{R}$ factor $\mathrm{R}_{\mathrm{Tem}}$ (Datta and Kontomichalou, 1965) was used as "standard ".

Aminoglycoside-inactivating enzyme. Streptomycin phosphorylase was determined by following the incorporation of ${ }^{32} \mathrm{P}$ from $\gamma-{ }^{32} \mathrm{P}$ adenosine triphosphate into streptomycin phosphate as described by Ozanne et al. (1969).

Isolation of R-factor DNA. Cultures $(10 \mathrm{ml})$ of $E$. coli $\mathrm{NC} 22$ strains carrying the three $\mathrm{R}$ factors were grown in minimal medium supplemented with methionine $(20 \mu \mathrm{g}$ per $\mathrm{ml})$, leucine $(20 \mu \mathrm{g}$ per $\mathrm{ml})$, thymine $(1 \mu \mathrm{g}$ per $\mathrm{ml})$, adenosine $(200 \mu \mathrm{g}$ per $\mathrm{ml})$ and with $3 \mathrm{H}$ thymidine $\left(100 \mu \mathrm{Ci}\right.$ at $5 \mathrm{Ci}$ per m.mole) or with ${ }^{14} \mathrm{C}$ thymidine $(30 \mu \mathrm{Ci}$ at $62 \mathrm{mCi}$ per m.mole) as previously described (Grinsted $e t$ al., 1972). The cultures were harvested and lysed, and the CCC DNA was separated from the chromosomal DNA by centrifugation in CsCl gradients containing ethidium bromide (Ingram, 1973).

Electron microscopy. Plasmid DNA preparations were diluted with ammonium acetate solution $(0.15 \mathrm{M})$ containing formaldehyde $(0.07 \mathrm{M})$ and mixed with cytochrome $\mathrm{c}$ (final concentration $2 \mu \mathrm{g}$ per $\mathrm{ml}$ ). The surface film of this mixture was picked off with carboncoated grids, fixed in ethanol and shadowed with platinum. Grids were examined in a Hitachi HS7S electron microscope and contour length of DNA preparations estimated on photographs; the value of $65 \times 10^{6}$ daltons was used for the molecular weight of R1 (Cohen and Miller, 1970). CCC-DNA preparations were converted to open circular forms for photography by freeze-thawing.

DNA-DNA hybridisation. The method of Denhardt (1966) modified as described by Anderson et al. (1973b) and Ingram (1973) was used to determine the DNA homology between pairs of R-factor CCC-DNA preparations.

$R$-factor transfer. Cultures of the donor and recipient were mixed and incubated statically at $37^{\circ} \mathrm{C}$ as previously described (Anderson et al., 1973b). Nalidixic acid $(100 \mu \mathrm{g}$ per $\mathrm{ml}$ ) was used for the counterselection for transfer to $E$. coli recipients and minimal medium containing nicotinic acid to select for transfer from auxotrophic $E$. coli strains to P. mirabilis.

Compatibility. $\mathrm{R}$ factors were transferred from the original $E$. coli isolates to strain UB276 $\mathrm{nal}^{\mathrm{r}}$. The strains were then used as recipients for the transfer of F- and I-type $R$ factors (R222 and 18M-1 tets). Strains carrying both sets of resistance determinants were grown for approximately 20 generations in nutrient broth and then replica-plated on to agar containing antibiotics to test for the presence of resistance markers.

\section{RESULTS \\ Resistance levels}

MIC values of a range of antibiotics were determined (table I) for $E$. coli strains carrying the three R factors R1 (ACKSSu), R157 (AST) and R174 (ACKSSuT). Resistance to ampicillin was quantitatively similar for the three strains; strains carrying R1 and R174 were both resistant to chloramphenicol, spectinomycin, and sulphonamide but the R157 strain was not; R157 and R174, but not R1 strains, were resistant to tetracycline. The resistance of the $E$. coli strain NxR carrying factor R174 was for each antibiotic at least equal to that of the more resistant member of the other two strains. Factors R157 and R174 conferred the same degree of resistance to streptomycin, which was higher than that conferred by R1. 


\section{Antibiotic-inactivating enzymes}

Because factor R157 conferred resistance to streptomycin, but not to spectinomycin, it seemed possible that it determined a streptomycin phosphorylase enzyme (Ozanne et al., 1969). The factors R157 and R174 were both

TABLE I

Minimum inhibitory concentration $(M I C)^{*}$ of autibiotics for Escherichia coli strain $N x R$ when carrying each of the three $R$ factors

\begin{tabular}{|c|c|c|c|c|c|c|c|}
\hline \multirow[b]{2}{*}{$\mathrm{R}$ factor $\dagger$} & \multicolumn{7}{|c|}{ MIC ( $\mu \mathrm{g}$ per $\mathrm{ml})$ for the strain, when carrying the indicated $\mathrm{R}$ factor, of } \\
\hline & $\begin{array}{l}\text { ampi- } \\
\text { cillin }\end{array}$ & $\begin{array}{l}\text { chloram- } \\
\text { phenicol }\end{array}$ & $\begin{array}{l}\text { kana- } \\
\text { mycin }\end{array}$ & $\begin{array}{l}\text { strepto- } \\
\text { mycin }\end{array}$ & $\begin{array}{l}\text { spectino- } \\
\text { mycin }\end{array}$ & $\begin{array}{l}\text { sulpha- } \\
\text { dimidine }\end{array}$ & $\begin{array}{l}\text { tetra- } \\
\text { cycline }\end{array}$ \\
\hline $\begin{array}{l}\text { R1 (ACKSSu) } \\
\text { R157 (AST) } \\
\text { R174 (ACKSSuT) }\end{array}$ & $\begin{array}{r}512 \\
256 \\
1024\end{array}$ & $\begin{array}{r}512 \\
2 \\
512\end{array}$ & $\begin{array}{r}1024 \\
2 \\
1024\end{array}$ & $\begin{array}{r}32 \\
128 \\
128\end{array}$ & $\begin{array}{r}256 \\
16 \\
256\end{array}$ & $\begin{array}{r}>2000 \\
32 \\
>2000\end{array}$ & $\begin{array}{r}1 \\
256 \\
256\end{array}$ \\
\hline
\end{tabular}

* On Oxoid DST Agar (see Anderson et al., 1973b), except for the aminoglycosides for which MIC values were determined on nutrient agar.

$\dagger$ Resistance to: $\mathrm{A}=$ ampicillin; $\mathrm{C}=$ chloramphenicol; $\mathrm{K}=$ kanamycin; $\mathbf{S}=$ streptomycin; $\mathrm{Su}=$ sulphonamide; $\mathrm{T}=$ tetracycline.

\section{TABLE II}

Streptomycin phosphorylase activity of extracts of Escherichia coli strain NC22 when carrying each of the three $R$ factors

\begin{tabular}{l|c}
\multicolumn{1}{c|}{ R factor $\dagger$} & $\begin{array}{c}\text { Streptomycin phosphorylated } \ddagger \\
\text { (p.moles per min. per mg of protein) }\end{array}$ \\
\hline R1 (ACKSSu) & $>0 \cdot 2$ \\
R157 (AST) & 3.6 \\
R174 (ACKSSuT) & 3.0 \\
\hline
\end{tabular}
text.

$\uparrow$ See footnote to table I.

$\ddagger$ The incorporation of $32 \mathrm{P}$ from 32P-adenosine triphosphate was determined as described in the

found to determine appreciable quantities of streptomycin phosphorylase whereas R1 did not (table II). E. coli strains carrying factor R1 were, however, resistant to spectinomycin as well as streptomycin, and it has been shown (Benveniste, Yamada and Davies, 1970) that streptomycin resistance coupled with spectinomycin resistance is determined by an adenylase enzyme. Because strains carrying factor R174 are resistant to spectinomycin as well as to streptomycin it is probable that these strains produce both an adenylase and the phosphorylase.

The characteristics of the penicillin resistance determined by each of the three $\mathrm{R}$ factors were examined by measuring the activity of $\beta$-lactamase in lysates of the three strains. All three strains contained comparable quantities of enzyme and this enzyme was inhibited to the same degree (figure) by 
antiserum prepared against type-IIIa $\beta$-lactamase (Datta and Richmond, 1966). It is thus probable that all three $\mathrm{R}$ factors determine the same type of $\beta$-lactamase, and the data suggest but do not prove that there is only one genetic locus for the enzyme in R174.

The resistance levels and enzyme characteristics are therefore consistent with factor R174 being a recombinant between factors R157 and R1.

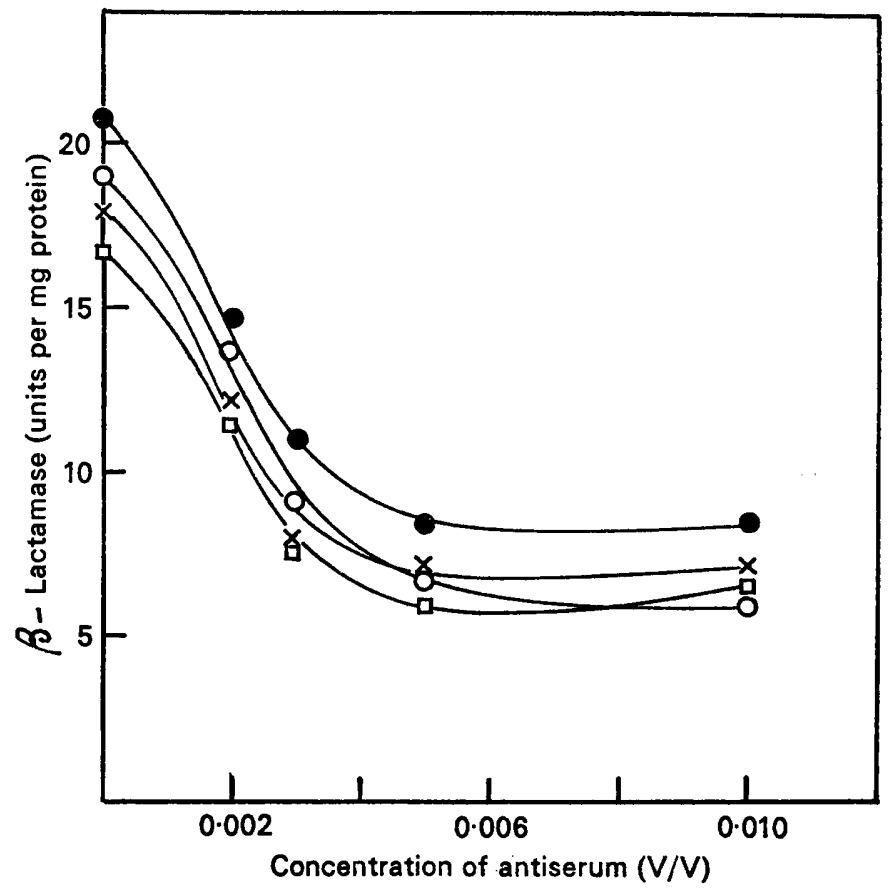

FIGURE.-Inhibition of $\beta$-lactamase from strains of $E$. coli carrying factors R1 (- - -), R157 (AST) (-๑) and R174 (ACKSSuT) ( $-\sqsubset \vdash)$ by antiserum prepared against type-IIIa $\beta$-lactamase. Lysate of a strain carrying the plasmid $R_{\text {Tem }}$ (Datta and Richmond, 1966) was used as a standard for type-IIIa $\beta$-lactamase $(-\times-)$.

\section{Molecular characteristics of the $R$ factors}

Lysates of isotopically labelled cultures of $E$. coli strain NC22 carrying each by the three $\mathrm{R}$ factors were examined by centrifugation through $\mathrm{CsCl}$ gradients in the presence of ethidium bromide. CCC DNA was shown to be present in the strains carrying the resistance factors R1 and R174, as previously reported (Anderson et al., 1973b), and also in strain NC22 carrying factor R157.

CCC DNA was isolated from these gradients and examined by electronmicroscopy to determine the contour length of the circular DNA and hence the relative size of the three DNA molecules (table III).

Table III also shows the extent of DNA-sequence homology between the three R factors. The DNA of R factor R174 is homologous with approximately $70 \%$ and $90 \%$ respectively of the DNA of factors R1 and R157, which 
suggests that it is composed of DNA from these two $\mathbf{R}$ factors. This requires either that factor R174 is at least $60 \%$ bigger than the other two $\mathrm{R}$ factors or that there is considerable homology between factors $\mathrm{R} 1$ and $\mathrm{R} 157$; this latter condition was found, as is shown in the table, and may explain why R157 was able to recombine with $\mathrm{R} 1$.

TABLE III

Molecular weight and hybridisation of the $R$ factors

\begin{tabular}{|c|c|c|c|c|}
\hline \multirow[t]{2}{*}{$\mathrm{R}$ factor* } & \multirow[t]{2}{*}{$\begin{array}{c}\text { Molecular weight } \dagger \\
\text { (daltons } \times 10^{-6} \text { ) }\end{array}$} & \multicolumn{3}{|c|}{$\begin{array}{l}\text { DNA sequences } \ddagger \text { (daltons } \times 10^{-}-6 \text { ) of the indicated } \\
R \text { factor that are homologous with DNA of strains } \\
\text { carrying factor }\end{array}$} \\
\hline & & $\mathbf{R} \mathbf{1}$ & R157 & R174 \\
\hline $\begin{array}{l}\text { R1 (ACKSSu) } \\
\text { R157 (AST) } \\
\text { R174 (ACKSSuT) }\end{array}$ & $\begin{array}{l}65 \\
65 \\
74\end{array}$ & $\begin{array}{l}3 \ddot{1} \pm 4 \\
55 \pm 5\end{array}$ & $\begin{array}{l}35 \pm 4 \\
6 \dddot{6} \pm 5\end{array}$ & $\begin{array}{l}55 \pm 5 \\
62 \pm 5 \\
\quad \ldots\end{array}$ \\
\hline
\end{tabular}

* See footnote to table I.

$\dagger$ Estimated by electronmicroscopy of CCC DNA isolated from $\mathrm{R}^{+}$strains of Escherichia coli strain NC22.

$\ddagger$ Determined by DNA-DNA hybridisation, values shown \pm standard deviation.

\section{Compatibility}

Datta and Hedges (1971) and Chabbert et al. (1972) have shown that $R$ factors can be classified into compatibility groups and that two plasmids of the same group are unable to co-exist in the same organism. The compatibility of factor R1 is known to be of F type, and factor R157 was tested by constructing strains carrying it and either the standard R factor R222 of factor $18 \mathrm{M}-1$. Strains carrying both factors R157 and 18M-1 (I type) showed over $80 \%$ segregation of the R-factor markers, whereas strains carrying factor R157 and R222 (F type) showed no segregation (at least 50 colonies tested for each pair of R factors). Factor R157 is thus probably in the I-compatibility group and is thus capable of co-existing with factor R1, which would tend to favour the formation of the strain carrying both plasmids that is necessary for recombination to occur.

\section{Transfer of $R$ factors}

The transfer characteristics of two of these plasmids were described in a previous paper (Anderson et al., 1973b); these observations were extended to R157, which gave a transfer frequency of about $10^{-3}$ per donor per hour, i.e., similar to the frequency transfer of factor R1. As previously reported, R174 gave a much lower transfer frequency, but when tested for transfer to $P$. mirabilis it gave a frequency of almost $10^{-2}$ per donor per hour which was much higher than that of the other two plasmids. This indicates that, even if factor R174 is a recombinant, its transfer properties have altered, and suggests also that the host strain is important for R-factor properties. 


\section{DisCuSSION}

The two R factors R1 (ACKSSu) and R157 (AST) with similar DNA-base sequences were the probable precursors of a third R factor R174 (ACKSSuT), which has combined the resistance determinants of the other two $R$ factors. This $\mathrm{R}$ factor was isolated (Anderson et al., 1973a) after the ingestion of a strain carrying factor R1 by a person who already carried the R factor R157 in another strain of $E$. coli. The experiment was carried out in the presence of ampicillin, which no doubt favoured the survival of strains carrying ampicillin resistance, but there was no selection pressure by this antibiotic for the formation of the recombinant because all the resistance factors carried ampicillin resistance. The possibility must be considered that factor R174 was formed by recombination between factors R157 and R1 after isolation of an $E$. coli strain carrying both separately. This is difficult to exclude, but the original strain was found to transfer all the resistance markers simultaneously shortly after it had been isolated, so that any recombination must have occurred in the primary isolation of the resistant strain if it did not occur in the gastro-intestinal tract.

In either case this study shows that an ingested resistant organism can transfer determinants which may later combine with a resident resistant plasmid to form a new multi-resistant $R$ factor. The organism carrying this new $\mathbf{R}$ factor might either dominate the faecal flora or transfer the $\mathbf{R}$ factor to a different organism if selection pressure were applied by treatment with further antibiotics (e.g., tetracycline after the initial use of ampicillin). Such sequential treatment is not unknown in clinical practice, e.g., in the treatment of urinary-tract infections, and hence may well be a factor leading to the emergence of highly resistant plasmids.

\section{SUMMARY}

A previous study described the isolation of multiply-resistant strains of Escherichia coli from the gastro-intestinal tract after the ingestion of a strain carrying an $\mathrm{R}$ factor (R1) that confers resistance to ampicillin (A), chloramphenicol (C), kanamycin (K), streptomycin (S) and sulphadimidine (Su). One such strain carried the R factor R174 (ACKSSuT) - which was in addition resistant to tetracycline (T)-and another carried the factor R157 (AST).

The minimum inhibitory concentrations of these antibiotics for $E$. coli strains, isogenic but for the $\mathbf{R}$ factors, were consistent with the formation of factor R174 by recombination of the AST and ACKSSu resistance determinants of the other two R factors. The factor R174 determined a streptomycinphosphorylase enzyme also present in factor R157, together with the streptomycin-spectinomycin resistance determinant of factor $R 1$, and all three $R$ factors shared the same type of ampicillin resistance. Factor R174 carried all the other antibiotic-resistance determinants (TCKSu) of the parent plasmids and is thus probably a recombinent of factor $\mathrm{R} 1$ and $\mathrm{R} 157$.

DNA-DNA hybridisation showed that factor R174 contained almost all of the DNA-base sequences of factors R157 and R1. There was also approxi- 
mately $50 \%$ homology between the latter two $\mathrm{R}$ factors which may account for the occurrence of recombination.

\section{REFERENCES}

Anderson, J. D., Gillespie, W. A. AND Richmond, M. H. 1973a. Chemotherapy and antibiotic resistance transfer between Enterobacteria in the human gastro-intestinal tract. J. med. Microbiol., 6, 461.

Anderson, J. D., Ingram, L. C., Richmond, M. H. and Wiedemann, B. 1973b. Studies on the nature of plasmids arising from conjugation in the human gastro-intestinal tract. J. med. Microbiol., 6, 475.

Benveniste, R., Yamada, T. AND Davies, J. 1970. Enzymatic adenylylation of streptomycin and spectinomycin by R-factor-resistant Escherichia coli. Infect. Immun., 1, 109.

Chabbert, Y. A., Scavizzi, M. R., Witchitz, J. L., Gerbaud, G. R. and Bouanchaud, D. H. 1972. Incompatibility groups and the classification of $\mathrm{fi}^{-}$resistance factors. J. Bact., 112, 666.

Clowes, R. C. 1972. Molecular structure of bacterial plasmids. Bact. Rev., 36, 361.

CoHEN, S. N. AND Miller, C. A. 1970. Non-chromosomal antibiotic resistance in bacteria. II. Molecular nature of R-factor isolated from Proteus mirabilis and Escherichia coli. J. molec. Biol., 50, 671.

Datta, N. ANd Hedges, R. W. 1971. Compatibility groups among $\mathrm{fi}^{-}$R-factors. Nature, Lond., 234, 222.

Datta, N. and Kontomichalou, P. 1965. Penicillinase synthesis controlled by infectious $\mathrm{R}$ factors in enterobacteriaceae. Nature, Lond., 208, 239.

DatTa, N. AND Richmond, M. H. 1966. The purification and properties of a penicillinase whose synthesis is mediated by an R-factor in Escherichia coli. Biochem.J., 98, 204.

DenHARDT, D. T. 1966. A membrane filter technique for the detection of complementary DNA. Biochem. Biophys. Res. Commun., 23, 641.

Farrar, W. E., Eidson, M., Guerry, P., Falkow, S., Drusin, L. M. and Roberts, R. B. 1972. Interbacterial transfer of an R-factor in the human intestine: in-vivo acquisition of R-factor-mediated kanamycin resistance by a multi-resistant strain of Shigella sonnei. J. infect. Dis., 126, 27.

Grinsted, J., Saunders, J. R., Ingram, L. C., Sykes, R. B. and Richmond, M. H. 1972. Properties of an R-factor which originated in Pseudomonas aeruginosa 1822. J. Bact., $110,529$.

INGRAM, L. 1973. Deoxyribonucleic acid-deoxyribonucleic acid hybridization of Rfactors. J. Bact., 115, 1130.

Ingram, L., Sykes, R. B., Grinsted, J., Saunders, J. R. ANd Richmond, M. H. 1972. A transmissible resistance element from a strain of Pseudomonas aeruginosa containing a detectable extrachromosomal DNA. J. gen. Microbiol., 72, 269.

Meynell, E. AND Datta, N. 1966. The relation of resistance transfer factors to the F factor (Sex factor) in Escherichia coli K12. Genet. Res., 7, 134.

Nisioka, T., Mitani, M. AND Clowes, R. C. 1970. Molecular recombination between Rfactor deoxyribonucleic acid molecules in Escherichia coli host cells. J. Bact., 103, 166.

Novick, R. P. 1962. Staphylococcal penicillinase and the new penicillins. Biochem. J., 83, 229.

Ozanne, B., Benveniste, R., Tipper, D. and Davies, J. 1969. Aminoglycoside antibiotics: inactivation by phosphorylation in Escherichia coli carrying R-factors. J. Bact., 100, 1144.

Perret, C. J. 1954. Iodometric assay of penicillinase. Nature, Lond., 174, 1012.

Watanabe, T. AND Fukasawa, T. 1961. Episome-mediated transfer of drug resistance in Enterobacteriaceae. III. Transduction of resistance factors. J. Bact., 82, 202.

Yokota, T., Kanamaru, Y., Mori, R. AND AkIBA, T. 1969. Recombination between a thermosensitive kanamycin resistance factor and nonthermosensitive multiple-drug resistance factor. J. Bact., 98, 863 . 